\title{
Spatial Analysis of Metal Content in Community Drinking Water Sources in Post Eruption of Sinabung Mountain in Karo District
}

\author{
Sri Malem Indirawati ${ }^{1}, \mathrm{Umi}_{\mathrm{Salmah}}{ }^{2}$, Lanova Dwi $\mathrm{Arde}^{3}$ \\ \{ srimalem@usu.ac.id ${ }^{1}$,umisalmah@usu.ac.id², lanovadwi@usu.ac.id ${ }^{3}$ \} \\ Public Health Faculty Universitas Sumatera Utara ${ }^{123}$
}

\begin{abstract}
Sinabung mountain in North Sumatra Province has been erupted since August 2010. The post-eruption conditions caused changes in land cover and had direct impact on the surrounding area. The community used drinking water sources from springs and wells which have been exposed to metals contained in volcanic ash eruptions. This study aims to analyze the chemical quality of community drinking water sources. Amount 21 samples of drinking water sources representing the direction of volcanic eruption were analyzed in the laboratory using Atomic Absorption Spectrometry method. Each sample point was analyzed by using the Inversed distance weighted (IDW) method. The results of the laboratory showed that Fe concentrations exceeded the environmental quality standard, while other metals still met the requirements for drinking water quality. The order of metal concentration in drinking water $\mathrm{Fe}>\mathrm{Mn}>\mathrm{Cd}>\mathrm{Pb}$. The results of correlation between distance and $\mathrm{Fe}$ concentration obtained value $\mathrm{r}=0.083$.
\end{abstract}

Keywords: Drinking water; metal; post-eruption

\section{Introduction}

Sinabung mountain in North Sumatra Province has been erupted since August 2010. The post-eruption conditions caused changes in land cover and had direct impact on the surrounding area. The community used drinking water sources from springs and wells which have been exposed to metals contained in volcanic ash eruptions. This can have an impact on public health. The eruption caused changes in environmental quality, especially affecting the quality of community drinking water sources which contain potentially toxic ions and metals [1]. The sources of water used by community in post-eruption residential area is obtained directly from springs and bore well. Minister of health Regulation No.32,2017 concerning clean water and water safety plan [2] Drinking water used must meet physical, chemical, microbiological and radioactive quality requirements.

The results of previous studies found $\mathrm{Pb}$ in the mount Sinabung's soil in at depth of $0-5 \mathrm{~cm}$ and $0-15 \mathrm{~cm}$ was $61.01 \mathrm{ppm}$ and $70.67 \mathrm{ppm}$, respectively [3]. Another research found that Sinabung volcanic ash contains element of iron was $0.58-3.1 \%$, sulfur $0.05-0.32 \%, \mathrm{~Pb} 1.5-5.3 \%$ [4]. The survey results in post-eruption settlement areas people complained about water quality. The purpose of this research is analyzing the chemical quality of community drinking water sources in Post eruption area and analyzing distance from center of eruption and concentration of metal in sources of drinking water. 


\section{Material and Method}

The location is in area of post eruption in Tanah Karo. This research is analytic survey with cross sectional design. The population is all sources of household drinking water in area of post eruption. There are 21 points of source of drinking water as a sample in the community of users borewell and springs. Amount 21 samples of drinking water sources representing the direction of volcanic eruption were analyzed in the laboratory using Atomic Absorption Spectrometry method. The locations of the sampling sites were recorded using portable GPS devices and are shown in Figure 1. Each sample point was analyzed by using the Inversed distance weighted (IDW) method. The radius distance from the center of eruption was $3-33 \mathrm{Km}$.

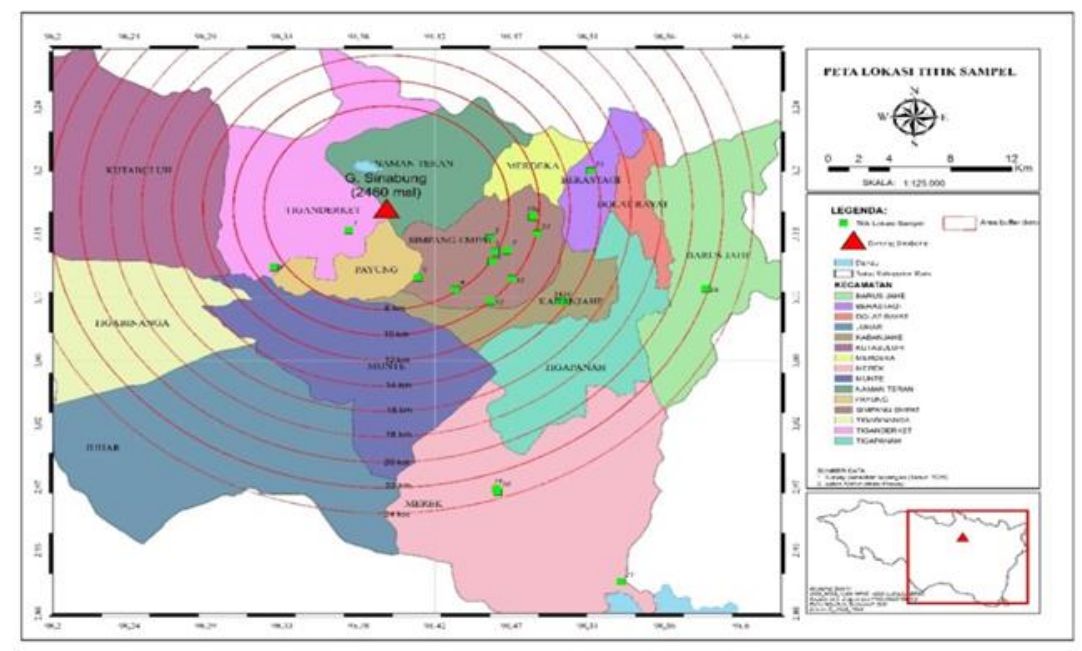

Fig 1. Research Location

\section{Result and Discussion}

The results of laboratory examination drinking water sources from 21 samples shown in table 1 below, four metal was analyzed the results shown that Fe exceeded the environmental quality standard based on the Minister of Health Regulation No. 492/Menkes/Per/IV/2010 concerned drinking water quality Requirements [5].

Table 1. Concentration of Heavy Metal

\begin{tabular}{llll}
\hline Metal & Higher $(\mathbf{m g} / \mathbf{l})$ & Lower $(\mathbf{m g} / \mathbf{l})$ & TLV $(\mathbf{m g} / \mathbf{L})$ \\
\hline $\mathrm{Fe}$ & 0.42 & 0.12 & $0.3 \mathrm{mg} / \mathrm{L}$ \\
$\mathrm{Mn}$ & 0.40 & 0.10 & $0,4 \mathrm{mg} / \mathrm{L}$ \\
$\mathrm{Cd}$ & 0.0034 & 0.001 & $0,003 \mathrm{mg} / \mathrm{L}$ \\
$\mathrm{Pb}$ & 0.001 & 0.0009 & $0.01 \mathrm{mg} / \mathrm{L}$ \\
\hline
\end{tabular}

The results of the laboratory showed that Fe concentrations exceeded the environmental quality standard, while other metals still met the requirements for drinking water quality. The presence of metals in the soil coming from the soil layer and also caused by the content of 
volcanic ash, both of them affected the water quality. Other research results on volcanic ash from mount Merapi contain various major elements ( $\mathrm{Al}, \mathrm{Si}, \mathrm{Ca}$ and $\mathrm{Fe}$ ), and minor ( $\mathrm{K}, \mathrm{Mg}, \mathrm{Mn}$, $\mathrm{Na}, \mathrm{P}, \mathrm{S}$ and Ti) [1]. Other case of presence $\mathrm{Fe}$ in the post-eruption area was described from results of examination nutrient content from volcanic ash was dominated by $\mathrm{Mn}, \mathrm{Fe}$ and $\mathrm{S}$ [6]. Torong river which is located in the Sinabung area at the downstream and upstream locations found Fe $1.2986 \mathrm{ppm}$ and $0,8762 \mathrm{ppm}$, respectively [7]. The results research in Nyamuragira in 2010 , found that the effect of eruption on the quality of drinking water in the community as the impact of Fe content in tldrinking water sources. During the 2010 eruption, concerns were expressed by local inhabitants about water quality and feelings of physical discomfort (e.g. nausea, bloating, indigestion, etc.) after consuming rain water collected after the eruption began [8].

\subsection{Fe concentration analysis and distances}

The analysis of Fe concentration with source of drinking water distances from mount Sinabung can be seen in figure 2 below. The results from inspections of 21 water sources in villages found that the highest concentration was $0.42 \mathrm{mg} / \mathrm{L}$ in two villages, namely Jandi meriah and Gajah which has distance from the center of eruption was $8.5 \mathrm{Km}$ and $9.55 \mathrm{Km}$. There are 15 village had concentration exceeded the environmental quality standard. Concentration of Fe below the environmental quality standard were found in 6 villages namely Perteguhen, Surbakti, Siosar, Situnggaling, Nang Belawan and Kabanjahe. Based of concentration from 6 villages, it was the lowest concentration $0.12 \mathrm{mg} / \mathrm{L}$ was at a distance 33.3 $\mathrm{Km}$ from the center of eruption. It found the higest concentration from the 6 villages was 2.8 $\mathrm{mg} / \mathrm{L}$ which distance from the center of eruption was 7.17 Km namely Perteguhen.

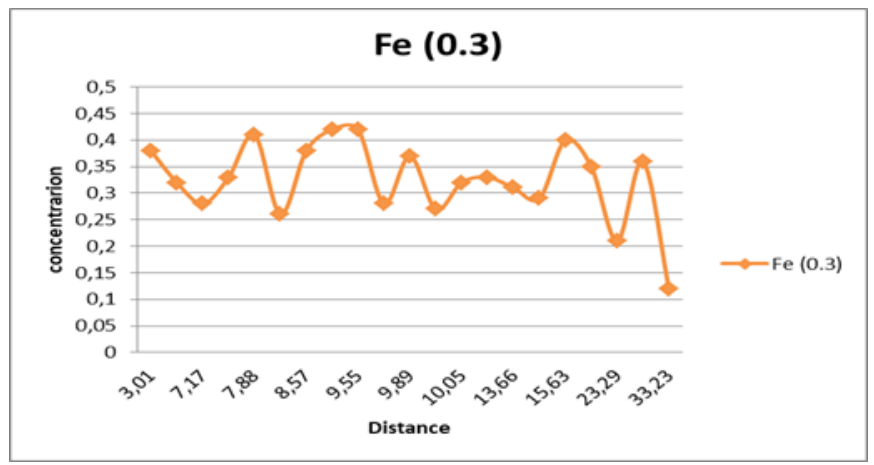

Fig 2. Graph of correlation distances and concentration of Fe

The results of analysis relationship between distance and Fe concentration showed a very weak correlation with a value of $r=0.083(\mathrm{pv}=0.098)$. It means that there is no correlation between distance and Fe concentration. It depends on the distribution of volcanic ash and content of metal in soil layer around. The results of spatial analysis in figure 3 below show that villages with $\mathrm{Fe}$ concentration exceeded the environmental standard was spread in the cardinal directions from east to west. It means that the direction of distribution of volcanic ash. 


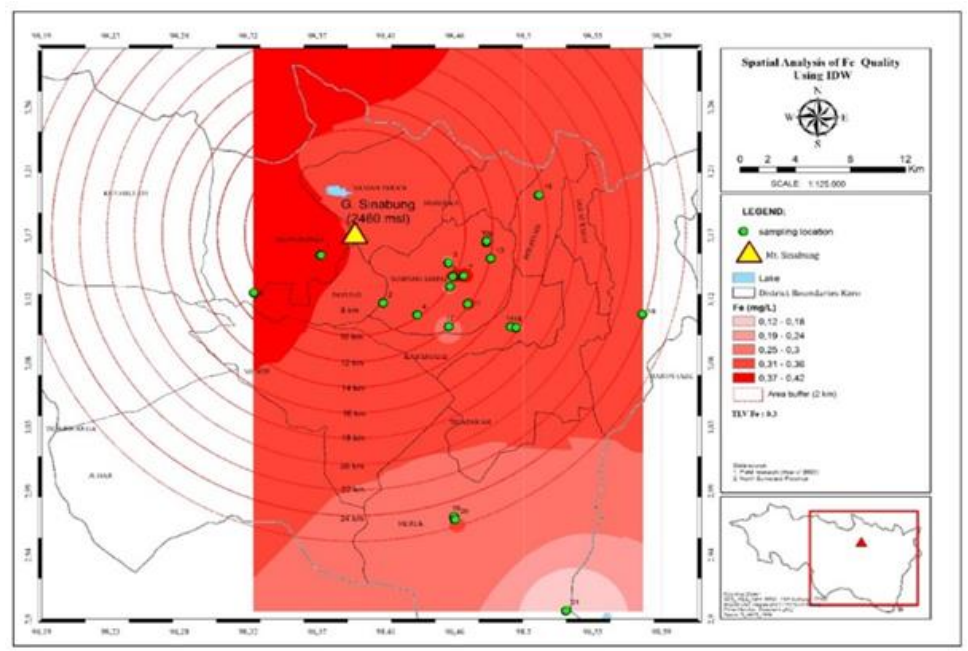

Fig 3. Spatial analysis concentration of $\mathrm{Fe}$ and distances from post eruption

The research found that the highest concentration was in Gajah, it could happen because the source of raw water comes from bore well and there has been no processing before like filtered. The distances of Gajah villages from the center of eruption were $8 \mathrm{Km}$ and it was lies in west of the mountain as direction of ash fall. It was different situation with Perteguhan which was $7.17 \mathrm{Km}$ distances from the center of eruption but the concentration below the environmental quality standard. It has sources of raw water from spring that has been treated and piped to the community. The presence of Fe in the soil and the structure of soil layer affects the water quality. The eruption of mount Merapi in 2010 showed the increase of $\mathrm{Fe}$ concentration in Code River. The results analysis of data before Merapi eruption the concentration was $0.05 \mathrm{mgl}$, after eruption it reached $0.3 \mathrm{mg} / \mathrm{L}$. It was seen that the increase reached 6 times $(60 \%)$ [9]

Research on contamination of water supplies in several areas' effects of volcanic ash on water quality in New Zealand, Vanuatu, Argentina, and other cities found concentration og Fe, $\mathrm{Al}, \mathrm{Mn}$, Sulfate and acidity increased in water supplies [10]. It marked the water undrinkable due to a bitter metal taste; color was dark and corrosive caused water deposition in the pipes. This condition will further effect on public health.

\section{Conclusion}

Fe concentrations exceeded the environmental quality standard, while other metals still met the requirements for drinking water quality. The order of metal concentration in drinking water $\mathrm{Fe}>\mathrm{Mn}>\mathrm{Cd}>\mathrm{Pb}$. The results of correlation between distance and Fe concentration obtained value $\mathrm{r}=0.083$ 


\section{Acknowledgements}

Acknowledgements to the chairman of Research Institute Universitas Sumatera Utara who has assisted in providing research fund. Many thanks to Head of Subdistrict Simpang Empat Tanah Karo who have given permission to carry out this research.

\section{References}

[1] Wahyuni E T. Triyono S. dan Suherma: Penentuan Komposisi Kimia Abu Vulkanik Dari Erupsi Gunung Merapi. Jurnal Manusia Dan Lingkungan 19 (2) pp.150-159 (2015)

[2] USAID: USAID Indonesia Urban Water, Sanitation and Hygiene Penyehatan Lingkungan untuk Semua (IUWASH PLUS) (2017) (online, https://www.iuwashplus.or.id/cms/wpcontent/uploads/2017/07/RPAM-info-sheet-ID-20170712.pdf diakses 20-02-2020)

[3] Barasa RF. Rauf A. Sembiring M: Dampak Debu Vulkanik Letusan Gunung Sinabung terhadap Kadar $\mathrm{Cu}, \mathrm{Pb}$, dan B tanah di kabupaten karo; Jurnal Online Agroekoteknologi Vol.1, No.4, September (1) pp.1288-1298 (2013)

[4] Endang Tri Wahyuni, Sugeng Triyono, dan Suherman : Determination of Chemical Composition of Vulcanic Ash from Merapi Mountain Eruption J. MANUSIA DAN LINGKUNGAN, Vol. 19 No. 2, Juli.pp.150-159 (2012)

[5] Permenkes 492/Menkes/Per/IV/2010 tentang Persyaratan Kualitas Air Minum. Jakarta Departemen Kesehatan RI

[6] Tindaon F, Tampubolon B dan Lumbanraja P: Komposisi Kimia Abu Erupsi Gunung Sinabung Tanah Karo dan Lumpur Vulkanik Sidoarjo Jawa Timur. Prosiding Seminar Nasional BKS PTN Wilayah Barat Bidang Ilmu Pertanian pp: 510-517(2016)

[7] Khairunnisa: Penentuan kadar logam Fe (fe), kadmium (cd) dan tembaga (cu) dari air sungai torong kawasan erupsi gunung Sinabung pasca erupsi dengan metode spektrofotometri serapan atom. (2015) Skripsi online, repositori.usu.ac.id/ bitstream/ handle/ 123456789/ 2688/ 140802066.pdf?sequence=1\&isAllowed=y diakses 20-02-2021)

[8] Emilio Cuoco, Dario Tedesco, Robert J. Poreda , Jeremy C. Williams, Stefano De Francesco, ,Charles Balagizi, Thomas H. Darrah: Impact of volcanic plume emissions on rain water chemistry during the January 2010 Nyamuragira eruptive event: Implications for essential potable water resources . Journal of Hazardous Materials, (244-245): 570-581 (2013)

[9] Bramantyo, Y., \& Purnama, I. L. S: Kualitas Airtanah Sub DAS Code Kota Yogyakarta Pasca Erupsi Merapi Tahun 2010. Jurnal Bumi Indonesia, 2(1), 77488 (2013).

[10] C. Stewart, D.M. Johnston, G.S. Leonard, C.J. Horwell, T. Thordarson, S.J. Cronin, Contamination of water supplies by volcanic ashfall: A literature review and simple impact modelling, Journal of Volcanology and Geothermal Research, Volume 158, Issues 3-4 pp. 296306 (2006) 